of systematic ascents, in order to inquire into the condition of the upper winds, and to measure their deftection or velocity, or their dimensions either in vertical or in horizontal directions.

Some of the readers of NATURE may possibly feel inclined to help me in working out these suggestions practically, or at least to ascertain if they are justified by facts as far as can be ascertained without travelling in the air.

W. DE FONVIELLE

\section{EARTHQUAKES IN THE PHILIPPINE ISLANDS}

CORRESPONDENCE from Manila, dated Oct. $17-18$, gives the following notice of earthquakes occurring there and in the neighbourhood on Oct. 16 , which may be of interest to some readers of NATURE :- -

\section{Manila.}

ro.12 A.M.--Hard shock; duration about I min. ; general direction from E.-W., but moving from S.E.N.W. to N.E.-S.W.

IO.I 5 A.M.-E. $25^{\circ}$ N.-W. $25^{\circ}$ S.; duration 5 sec.; rotation from E.-N.

10.20 A.M. till IO. 5 P.M.-Thirty-seven other light shocks, i.t. in the whole thirty-nine shocks in twelve hours.

The interval of these shocks became at last greater and greater in the following order:-

\begin{tabular}{|c|c|c|c|c|c|c|c|}
\hline 10.20 & A.M. & 11.20 & A.M. & 12.2 & P.M. & 12.55 & $\bar{I}^{2}, \mathrm{~B}$ \\
\hline 10.25 & 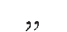 & I 1.23 & ,y & 12.19 & 3 & 1.9 &, \\
\hline 10.30 & " & I 1.26 & " & 12.20 & , & 1.52 & , \\
\hline 10.40 & $"$ & 11.31 & " & 12.22 & ; & 2.40 & 9 \\
\hline 10.43 & $y$ & I. 34 & $"$ & 12.24 & " & 4.2 & ") \\
\hline 10.46 & 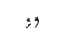 & $\mathrm{II} .4 \mathrm{I}$ & " & $12.3 \mathrm{I}$ & \# & 6.25 & "? \\
\hline 10.50 & , & II. 44 & $\therefore$ & 12.42 & $"$ & 8.15 & $\because ;$ \\
\hline 10.51 & ", & 11.46 & $\Leftrightarrow$ & 12.45 & $"$ & 9.15 & "Y \\
\hline 11.12 & " & 11.58 & $"$ & 12.50 & $\%$ & 10.15 & ; \\
\hline II. I 5 & , & & & & & & \\
\hline
\end{tabular}

IO.S A.M.-Hard shock.

ro.1 A A.M. till I P.M.-Lighter shocks.

$$
\text { Pampanga. }
$$

ro.13 A.M.-N.W.-S.E. Hard shock; duation 50 sec. IO.2I A.M.-Duration 20 sec.

12.3O P.M.--Light slunck.

\section{Persigasilant}

10.25 A.M.-S.E.-N.W. Duration $26 \mathrm{sec} ;$ wirht shock.

$$
\text { Crriti: }
$$

10.) I A.M.-Light shock.

10.45 A.M.-Light shock.

I2.I 3 P.M.- Light shock.

\section{Batangrys.}

10.2 A.M.-E.-W. Two shocks, of $10 \mathrm{sec}$ and $7 \mathrm{sec}$. duration.

$$
\text { Lagrina. }
$$

Light shock; 2 sec. duration.

Royal Natural Hist. Museum, Dresden, Dec. 25

\section{A. B. MEYER}

\section{THE TRANSIT OF VENUS}

THE following telegrams have been received during the past week :-

From Prof. Peters, viit Wellington, New Zealand :-

"Transit observation great success first contact; photographs, 237."

"New' York, Dut 31.-Intelligence has been received here from Honolulu, dated the 12 th inst, respecting the observations of the Transit of Venus at that station. The atmospheric conditions were favourable for the observations; I50 measures of cusps and limbs and 60 photographs were obtained. A totally unexpected appearance was presented at the internal contact. The disc of the planet became visible as an entire circle some minutes before contact, and from then to the complete establishment no definite or sudden phase was observed. There was no black drop after the internal contact. Twenty out of sixty photographs came out blurred. Valuable results, however, were obtained. The first external contact occurred at $3 \mathrm{~h} .7 \mathrm{~m}$., and the first internal contact at two minutes later than the Britis/ Nautical Almanack stated. The revelation of the complete circle of the planet occurred before the actual internal contact, owing to the effulgence of the corona, the sun illuminating the whole surface of Venus before the complete immersion."

In connection with the news from Honolulu, an article in the Times of Tuesday says :- "The most remarkable part about it is that the observers evidently regarded as an 'unexpected appearance' a phenomenon similar to one observed and recorded in the former transits of $176 \mathrm{I}$ and 1769 . In the observations of Chappe d'Auteroche in the latter year, recorded by Cassini, a drawing is actually given of the horns of Venus visible beyond the edge of the sun, and it seems probable from the text that the planet was actually seen on the sun's chromosphere at the moment of egress."

Incleed, this phenomenon need not have caused any surprise if the conditions had been previously clearly understood. In reference to this point, some statements from the Daily Neaws Thebes correspondent (Dec. 9) are worth quoting. In speaking of the commencement of the phenomenon the correspondent says Venus "appeared anything but a promising subject for the purpose at first. She seemed literally to dance about the face of the sun, and her limb was jagged like a saw. They both appeared elliptical in an almost extraordinary degrec, owing of course to refraction, and they did not lose it entirely till they were at least $7^{\circ}$ from the horizon. Gradually the limbs of both got more and more defined, till Venus looked like a small black pea resting on a luminous disc. The sun, however, still remained somewhat troublesome, paxticularly to the photographers, and it was not till just before internal contact that he was really steady. The atmospliere of Venus was distinctly seen at certain poiods. It sbowed as a pale white circle round part of her edge, and was totally difurent to the brilliant sunlight. The general remark was that it reminded us of moonlight. This caused a certain diffculty in estimating the true time of contacts, and perhaps any small discrepancy in observation may be accounted for by this phenomenon. . . There is one curious coincidence to note, and that is, that no one seemed to have observed the black drop which has been so much talked about; a faint haze was seen, and a few jets of black springing out from each side of the point of contact, but nothing more. Neither in the photographs did it show, which pernaps might have been expected. Certainly, the weather could not have been more favourable just at the critical time, though, curiously enough, immediately after, a haze came on, which would seriously have affected the results. Need I say that we are all thankful the observation has passed off so well, and if only the other stations to which expeditions have been sent are equally fortunate, the sun's distance ought to be definitely settled. I fully expect that the appearance of the faint line will give rise to a long discussion in the astronomical world. It will be very curious to note what other stations saw. At all events one thing is certain, and that is that our atmosphere must have been very clear, and also that of Venus; clouds in the planet must have intercepted the sunlight, and have prevented the formation of the luminous ring, or rather partial ring. At one time the whole planet, when 
it had half passed over the limb of the sun, was visible, reminding one of the dark part of the new moon on a clear night. I may say that the whole appearance of internal contact was quite unexpected, and the absence of the black drop puzzled every observer. External contact was observed, I hear, almost simultaneously by all observers, a point of the utm ost importance when the degree of ellipticity of the planet has been determined from measurements of her diameter."

\section{NOTES}

Tine Germans, we are glad to $\mathrm{sec}$, have fimally decided to send out a second expedition to the cast coast of Greenland. It is to consist of two stcam-vesscls, of 300 tons burden, each manned by thirty men; one to explore Greenland, while the other advances to the north pole. The estimated cost is about $50,000 \%$ sterling, and the expedition is to leave in June 1875 or June 1876 , according as the money can be got together. There is no hint that the German Government is to lend assistance, thougl we hope it will do something, after such a grood example has been set by our own Government. It would be a splendid and healthy outlet for national rivalry to have these two expeditions start this year, each doing its best to win the Arctic campaign, and striving to be the first to unfurl its particular national flas over the long-fought-for goal. At all events, during the next two or three years we ought to hear of some fine conquests having been made in the far north. The preparations for our own expedition are steadily progressing. Commander Markham, R.N., arrived on Tuesday at Portsmouth.

ONE of the principal articles in this month's Geosraphical Mugracine is on Lieut. Cameron's recent discoveries in the 'Tanganyika region. The writer justly rates Licut. Cameron's work as of the highest importance, and we earnestly hope that the appeal of the Royal Geographical Socicty for subscriptions to enable Cameron to complete his work will be liberally responded to. Aready 1,494 . have been subscribed, including 500\%. from the Gcographical Socicty; but of this, 544\% will be swallowed up by expenses already incurred, so that there is really only 9502 . available. This, "it is confidently hoped, will be largely increased as soon as the people of England are fully aware of the necessities of their young conatryman in the heart of Africa, and of the rorious wot that he is bravely attenipting to do, alone and single-handed."

DR. ALLCIIN will give the course of lectures on Comparative Anatomy and Zoology this session at University College, London, pending the appointment of a successor to the late Prof. Grant. The introductory lecture will be delivered to-day, at 4 I.M.

Mr. Bowbtur Sinkr, of the Tritish Muscum, delivered a lecture on "The lBirds of our Globe," on Tuesday, Jamury 5, in the private music-room at Mr. N. ILolmes's residence, I'ninrose IIII. The lecturer, commeneing with the "Accipitres," or birds of prey, gave a concise description of the various families and genera of birds, terminating, according to modern classification, with the "Struthiones," illustrating at the same time the different groups by an elaborate series of paintings specially prepared for the occasion by IIerr Keulemans, the well-known ornithological artist.

Wo have received a foretaste of the forthcoming new edition of the "Encyclopedia Britannica," in the shape of a separate reprint of Mr. A. R. Wallace's carefully written article on "Acclimatisation." After an examination of a considerable number of instances, Mr. Wallace concludes: "On the whole, we seem justified in concluding that, under favourable conditions, and with a prover adaptation of means to the end in view, men may become acclinatised with at least as much certainty and rapidity (counting by generations rather than by years) as any of the lower animals."

Tuls great hurricane which swept over Hong Kong on the 22nd and $23 \mathrm{rd}$ of September last, and to which we referred at length linst week, appears, from official reports, to have caused considerable damage in the Government Gardens. Mr. Ford, the superintendent, reports that the largest trees suffered the most severely, several of the oldest and largest being entirely destroyed. Many other trees, although not destroyed, were severely damaged, having nearly the whole of their branches broken off, while many which were thus damaged, but which had not their roots broken or strained, will, in course of time, produce fresh branches and foliage. A considerable number of smaller trees and shrubs were entirely destroyed, having been broken off close to the ground, while others were blown over and a 'great portion of their roots so much exposed to air and light as to threaten their ultimate destruction. Operations were at once commenced for the preservation of as many of the trees and shrubs as there was any prospect of saving, and the greater part of them were replanted and pro. tected by supports. The flower-pots containing plants in various parts of the gariens were broken in great numbers, and the plants for the most part much disfigured. In the nurseries, likewise, the plants in pots were thrown out, but no serious damage was effected. With regard to trees in different parts of the town, which come under the Forest Department of Hong Kong, Mr. Ford says: "I have observed that in nearly all cases where trees were blown down in the typhoon of September I $87 \mathbf{I}$, and those trees were again set upright and have continued to grow up to the late "typhoon, they have again fallen, and in several cases are this time entirely destroyed; thus proving, as a general rule, that when once a tree suffers so severely as to cause its prostration, little reliance can be placed on that tree ever afterwards continuing or becoming a solind and healthy one." In the Surveyor-General's Report to the Colonial Sccretary of Hong Kong: on the damage caused by this hurricane, it is regretted that no record remains of the pressure of the wind, owing to the meteorological station connected with the Government Ifospital being swept away by its force. It is further said, however: "That the island was not many miles distant from the fous of the cyclone is prowed not only by the intensity of the wind, but by a fature known to exist oniy within such a focus, namely, the abrupt intervals of calm during the height of the gale. These lalls were instantaneous, ofter lasting as long as four or fre minutes; and, alternaing with the most violent gus!s, equally sudden, the conjoint action of the two became, as it were, that of a battering ram."

MaNy experiments have been tricd in France to test the effects of cold on railway axlcs. Many engineers suppose that accilents to wheels do not result from any dininution of tenacity of the metal, but merely from its losing all its elasticity owing to the frost hardening the surface of the earth. A fact which can be adduced as a strong argment in favour of that theory was observed by the inhabitants of Montmartre during the last period of frost. The passing of the trains which run so frequently through the liatignolles tumel at a distance of hall a mile was heard by them day and night, which is never the case in ordinary circumstances. As soon as the thaw set in the trains ceased to be heard ; the earth having resumed its former elasticity, the sounds were dissipated as before. It has been observed by French railway engineers that thaws are apt to lead to the lreaking of axles and chains. The elasticity being only partially recovered, many shocks affect the irains when ruming at a fast rate, and are apt to lead to catastrophes.

MR. IV. Phildips, of Shrewsbury, proposes to publish, under' the title of "Elvellacei Britannici," dried specimens of the larger 